\section{Decisive and strong leadership and intersectoral action from South Africa in response to the COVID-19 virus}

To the Editor: South Africa (SA) reported its first case of coronavirus disease 2019 (COVID-19) on 5 March 2020. For the 14 days from then until the time of writing (5 - 19 March), we have seen decisive, strong leadership from the President, and significant, important and necessary co-ordination between different ministries including Education, Justice, Health, Trade and Industry, Transport, Public Works and Infrastructure, Finance, Cooperative Governance and Traditional Affairs, and International Relations and Cooperation. In these 14 days, SA has rapidly produced and implemented a number of action items (Table 1). This intersectoral action and co-ordination is something that has been needed for a long time to address development in SA.

On 19 March 2020, the Competition Commission published a COVID-19 block exemption for the healthcare sector. ${ }^{[1]}$ The exemption is aimed at promoting co-ordination, sharing of information and standardisation of practice across the entire healthcare sector. It also seeks to facilitate cost reduction measures, in particular costs of diagnostic tests, treatment and other preventive measures. Finally, the exemption seeks to promote agreements between the National
Department of Health and the private sector, with the sole purpose of making additional capacity at healthcare facilities available to the public sector and ensuring adequate medical supplies. COVID-19 has dramatically highlighted the need for a significantly more integrated healthcare system.

The Health Market Inquiry (HMI) made recommendations that will promote standardisation and knowledge sharing as well as a method to deal with pricing within the functions of the proposed supply-side regulator. Perhaps this exemption can build trust between players and will ease us into a more rational and integrated healthcare system.

Evidence from the HMI showed an excess capacity of high-care and intensive care unit (ICU) beds in the private healthcare sector, and the HMI concluded that there was inappropriate use of these beds. ${ }^{[2]}$ To free up private sector ICU beds will require the private sector to change its criteria of how they are used. Hospitals will also have to improve general ward care if this is one of the reasons doctors prefer to admit to an ICU, as was reported to the HMI. Improving general ward care will improve efficiency to the benefit of all.

Another area that requires coherence between the public and private sectors is COVID-19 testing. Public sector testing at the moment is in our opinion correctly restricted to individuals who meet the case definition. A live broadcast of a question and answer

Table 1. List of key actions ${ }^{\star}$

\begin{tabular}{|c|c|}
\hline Ministry & List of actions taken \\
\hline President & $\begin{array}{l}\text { Declaration of a State of Disaster in terms of section } 27 \text { of the Disaster Management } \\
\text { Act No. } 57 \text { of } 2002\end{array}$ \\
\hline Health & $\begin{array}{l}\text { Establishment of a national hotline and WhatsApp number for the general } \\
\text { population }\end{array}$ \\
\hline Home Affairs, International Relations and Cooperation & $\begin{array}{l}\text { Travel ban on foreign nationals from high-risk countries such as Italy, Iran, South } \\
\text { Korea, Spain, Germany, the USA, the UK and China as from } 18 \text { March } 2020\end{array}$ \\
\hline Health & $\begin{array}{l}\text { Dedicated website with daily updates from the National Institute for Communicable } \\
\text { Diseases, tests conducted, positive and negative results, information on symptoms } \\
\text { and prevention (in local languages), list of amended regulations }\end{array}$ \\
\hline Defence and Military Veterans & $\begin{array}{l}\text { 'Release of resources' by the Department of Defence, national organs of state, and } \\
\text { institutions in national, provincial and local government }\end{array}$ \\
\hline Police & $\begin{array}{l}\text { 'Prevention and prohibition of gatherings.' In this case, a gathering of } 100 \text { people is } \\
\text { prohibited. The assembly of more than } 50 \text { persons at premises where liquor is sold } \\
\text { and consumed is also prohibited. The Regulation also makes provision for powers } \\
\text { of an enforcement officer to disperse a gathering, or in some cases to arrest and } \\
\text { detain the organiser of a gathering. }\end{array}$ \\
\hline Trade and Industry & COVID-19 Block Exemption for the Healthcare Sector \\
\hline Health, Justice and Correctional Services & $\begin{array}{l}\text { 'Refusal of medical examination, prophylaxis, treatment, isolation and quarantine'. } \\
\text { This regulation makes provision for the unlikely scenario where a person refuses } \\
\text { to (self) quarantine or (self) isolate. The person may then be placed in isolation or } \\
\text { quarantine for a period of } 48 \text { hours, as the case may be, pending a warrant being } \\
\text { issued by a magistrate, on application by an enforcement officer, to perform the } \\
\text { medical examination of a suspected or confirmed case. }\end{array}$ \\
\hline Public Works and Infrastructure & $\begin{array}{l}\text { 'Places of quarantine and isolation' by the Minister of Public Works and } \\
\text { Infrastructure, the Members of the Executive Council in the provinces and the } \\
\text { accounting officers of municipalities }\end{array}$ \\
\hline Basic Education and Higher Education, Science and & 'Closure of schools and partial care facilities' from 18 March 2020 until 15 April \\
\hline Technology & $\begin{array}{l}2020 \text {, which period may be extended for the duration of the national State of } \\
\text { Disaster by the cabinet member responsible. }\end{array}$ \\
\hline Justice and Correctional Services & $\begin{array}{l}\text { Suspension of visits for } 30 \text { days to correctional centres, remand detention facilities, } \\
\text { holding cells, military detention facilities and Department of Social Development } \\
\text { facilities, including child and youth care centres, shelters, one-stop centres and } \\
\text { treatment centres, which period may be extended for any period, but not beyond } \\
\text { the duration of the national State of Disaster, by the cabinet member responsible. }\end{array}$ \\
\hline
\end{tabular}


Table 1. (continued) List of key actions ${ }^{\star}$

\begin{tabular}{ll}
\hline Ministry & List of actions taken \\
\hline Health, Police, Justice and Correctional Services & 'Limitation on the sale, dispensing or transportation of liquor.' In this case all \\
& on-consumption premises selling liquor, including taverns, restaurants and clubs, \\
& must be closed with immediate effect, or must accommodate no more than 50 \\
& persons at any time, provided that adequate space is available and that all directions \\
& in respect of hygienic conditions and limitation of exposure to persons with \\
& COVID-19, are adhered to. It is also notable that no special or events liquor licences \\
& will be considered for approval during the duration of the national State of Disaster. \\
& Establishments will also close earlier, between 18 h00 and 09 h00 the next morning \\
& on weekdays and Saturdays, and from 13h00 on Sundays and public holidays. \\
& 'Emergency procurement procedures' in line with financial management legislation, \\
& regulations and instructions. \\
Finance/Treasury & 'Authority to issue directions.' In this regard, the Ministers of Health, Justice and \\
& Correctional Services, Basic and Higher Education, Police, Social Development, \\
President & Trade and Industry, and Transport have been authorised to issue directions where \\
& needed to address, prevent and combat the spread of COVID-19 in matters falling \\
& within their respective mandates. \\
'Offences and penalties' for a person when found liable on conviction, to a fine & or imprisonment for a period not exceeding 6 months, or both such fine and \\
imprisonment. &
\end{tabular}

session organised by the South African Medical Association and the Minister of Health revealed that general practitioners were inundated with requests for testing that the GPs thought was not indicated. There were also reports that some employers demanded that employees arrive at work with a confirmed negative test result. This is irrational - a negative test today does not mean a negative test tomorrow - and furthermore it is not constitutional. SA's experience with HIV testing has confirmed the unconstitutionality of demanding people's confidential medical results through the courts. Education of some employers is clearly required. Over and above this, testing the worried well for COVID-19 is a waste of resources.

We should not be naive, and must consider that profiteers both from the public and private sectors, in equal measure, may try to take advantage of this situation. Oversight of the resources that are being invested in protecting SA from the COVID-19 virus must be exercised.

The threat that COVID-19 presents has resulted in leadership from government and apparent willingness of all South Africans to play their part. However, SA faces just as real a threat to its health, its economy and its development: the crises of poverty, inequality and unemployment are the social determinants that threaten our wellbeing as individuals and as a society at large. We would have a healthier country if we could demonstrate the same degree of intersectoral action and social mobilisation across the public/private divide in the form of meaningful social compacts. There are excellent lessons to be learnt here, and this opportunity should not be wasted.

\section{Lungiswa Nkonki}

Department of Global Health, Division of Health Systems and Public Health, Faculty of Medicine and Health Sciences, Stellenbosch University, Cape Town, South Africa

lnkonki@sun.ac.za

\section{Sharon Fonn}

School of Public Health, Faculty of Health Sciences, University of the Witwatersrand, Johannesburg, South Africa

\footnotetext{
1. Ngcobo S, Fonn S, Bhengu N, van Gent C, Nkonki L. Health Market Inquiry: Final Findings and Recommendations Report. Pretoria: Competition Commission of South Africa, 2019. http://www. compcom.co.za/wp-content/uploads/2020/01/Final-Findings-and-recommendations-report-HealthMarket-Inquiry.pdf (accessed 24 March 2020)

2. Department of Trade and Industry, South Africa. Competition Act (89/1998), as amended: COVID-19 Block Exemption for the Healthcare Sector, 2020. Government Gazette No. 43114, 19 March 2020. (Published under Government Notice R. 349.) https://www.gov.za/sites/default/files/gcis_ document/202003/4311419-3dti.pdf (accessed 19 March 2020).
} 